\title{
Foreign Language Identity and its Relationship with Travelling and Educational Level
}

\author{
Ebrahim Khodadady (Corresponding author) \\ Department of English Language and Literature, Ferdowsi University of Mashhad, Mashhad, Iran \\ Tel: 98-915-157-0733 E-mail: ekhodadady@ferdowsi.um.ac.ir
}

Safoora Navari

Department of English Language and Literature, Ferdowsi University of Mashhad, Mashhad, Iran

E-mail: safoora.navari@gmail.com

Received: September 12, 2011

Accepted: October 27, 2011

Published: March 1, 2012

doi:10.5539/elt.v5n3p30

URL: http://dx.doi.org/10.5539/elt.v5n3p30

\begin{abstract}
This study explored the relationship between identity and learning English by designing and administering a 30 -item Foreign Language Identity Scale (FLIS) to 470 female participants enrolled in English courses offered at advanced levels in private institutes in Mashhad, Iran. The application of the principal axis factoring to the responses and rotating the factors resulted in extracting six latent variables, i.e., idealized society, idealized communication, idealized means, idealized opportunities, global connection, and global self-expression, explaining forty percent of variance in the FLIS. With the exception of the last, the first five factors revealed strong interrelationships among themselves and thus showed that female Iranians in Mashhad learn English by creating an identity in an idealized society in which they can acquire the means to communicate best and find the opportunity they lack, reveal and improve the personality they possess, get better jobs and connect to the rest of the world. The foreign language identity, however, seems to disappear when the learners go abroad and study at universities.
\end{abstract}

Keywords: Identity, Foreign language, Idealization, Higher education

\section{Introduction}

Kanno (2000) defined identity as "a person's understanding of who they are" (p.2) and McKinley and Sakamoto (2007) extended it to "an understanding of self in a given context" (p.8) after they posed seven open ended questions to 40 Japanese sophomore students majoring in English language in Japan and analysed their reasons why they did not adhere to their English in their class discussions and switched to Japanese arbitrarily. These students spoke the former as their second language (SL) because they had lived and used it as a language of communication in an English speaking country before they returned to Japan with their families.

Speaking English, according to Hashimoto (2000), involves a conflict between being a Japanese and behaving like a foreigner because it requires an 'individualistic' and 'aggressive' (Mouer \& Sugimoto, 1986, p.399) mode of life running counter to Japanese innate shyness. After reviewing the answers given to the seven open-ended questions and interviewing their participants in order to have a better insight into their responses, McKinley and Sakamoto (2007) concluded that their fully proficient in-English-participants compromised the use of their second language skills in order "to assure social acceptance and harmony" (p. 26), i.e., they avoided speaking English whenever they could and switched to Japanese to reveal their shyness.

For some scholars, however, identity seems to be more than the understanding of self because its definition has escaped a clear demarcation so far. Menard-Warwick (2005), for example, brought up the fact by describing the current situation as "definitional confusion in the literature" (p. 254). She offers Ochs' (1993) definition of identity i.e., "a cover term for a range of social personae, including social statuses, roles, positions, relationships, and institutional and other relevant community identities one may attempt to claim or assign in the course of social life" (p. 288), as the most precise. Menard-Warwick does, nonetheless, believe that even Ochs' definition is vague because it includes the words "cover term" and "a range."

In spite of being long and detailed, Ochs' (1993) definition has firmly established identity as a social trait. It was, however, Tajfel (1981) who originally referred to social identity as individuals' membership in a social group and 
argued that if their emotional needs were not met by their identification with a certain group, they would change their affiliation. Giles and Johnson $(1981,1987)$ developed Tajfel's idea into an ethnolinguistic identity theory by suggesting language as a prominent marker of social identity. Sociolinguists such as Gumerz (1982) and Heller (1987, 1995, 1999, and 2001) extended the idea to the establishment of shared and unshared memberships by willfully adopting a given language to signal the type of membership.

In contrast to scholars such as Ochs (1993) and Tajfel (1981) who have studied language as a means of social identity within an SL context where its users can choose between their first and second languages to signal their willfully adopted identity, we have approached English as a means through which an idealized identity is established in a foreign language (FL) context. In McKinley and Sakamoto's (2007) study, for example, Japanese students deliberately avoided speaking English with their classmates all the time and switched to Japanese occasionally to emphasize their innate shyness as their social identity. This study is, however, based on the premise that an FL such as English in a country such as Iran is learned because it provides its learners with an idealized identity free from the obstacles they face in the society in which their mother language is spoken as a means of social identity.

\section{Methodology}

\subsection{Participants}

Four hundred seventy advanced female learners of English were chosen to take part in the study. Their age ranged from 15 to $45($ mean $=24.02, \mathrm{SD}=6.28)$. No beginners or intermediate learners were included because the researchers assumed that their lack of proficiency would not let them establish their identity in English as a foreign language. One hundred twenty four (26.4\%), 108 (23\%), $76(16.2 \%), 61(13 \%)$ and $56(11.9 \%)$ of the participants were studying at Kish, Azaran College, ILI, Safir and Jihad Deneshgahi institutes, respectively. These six private language centers enjoy the enrollment of a large number of English learners due either to their affiliation to universities or to their popularity in Tehran and having branches in the capitals of most provinces in Iran.

The participants held a high school diploma $(n=60,12.8 \%)$, above diploma $(26,6.2 \%)$, BA/BSc $(n=260,55.3 \%)$, MA/ MSc/MD $(\mathrm{n}=58,12.3 \%)$ and $\mathrm{PhD}(\mathrm{n}=2,0.4 \%)$ in humanities $(\mathrm{n}=177,37.7 \%)$, technical and engineering $(\mathrm{n}$ $=135,28.7 \%)$, science $(\mathrm{n}=58,12.3 \%)$, medicine $(\mathrm{n}=21,4.5 \%)$, arts $(\mathrm{n}=12,2.6 \%)$ and other unspecified fields $(\mathrm{n}$ $=67,14.3 \%)$. Three hundred thirty two (70.6\%) were single and $138(29.4 \%)$ had married. Out of 470 participants $166(35.3 \%)$ had travelled abroad, among whom six (5.41\%) had visited Canada, England and India where English is spoken as a first and second language. The other visited countries were Saudi Arabia $(\mathrm{n}=31,18.67 \%)$, United Arab Emi $(n=17,10.24 \%)$, Iraq $(n=12,7.23 \%)$, Turkey $(n=9,5.42 \%)$, Azerbaijan $(n=5,3.01 \%)$, Lebanon $(n=2$, $1.20 \%)$, Afghanistan $(n=1,0.6 \%)$, Armenia $(n=1,0.6 \%)$ and Syria $(n=1,0.6 \%)$.

\subsection{Instrument}

The instrument employed in this study consisted of two parts, i.e., biodata and FLIS.

\subsubsection{Biodata}

The Biodata part of the instrument comprised 17 items asking the participants to specify the institute where they studied English, their level of English proficiency, the fields of study at university, degree and branch of study, age, gender, mother language, the foreign countries they had visited, the duration of their visit and whether they were planning to go abroad.

\subsubsection{Foreign Language Identity Scale}

Based on the discussions brought up in the researchers' own classes, the 30 -item foreign language identity scale (FLIS) was developed on a 7-point Likert scale in Persian and the values of $0,1,2,3,4,5,6$, and 7 were assigned to no response, totally disagree, almost disagree, disagree, no idea, agree, almost agree and totally agree, respectively. All the statistical analyses were run on these seven points. For the ease of interpretation, however, points 1, 2 and 3 were collapsed to form a single point called disagree. Similarly, points 0 and 4 were collapsed to form no idea point as were points 5, 6, and 7 to establish the agree point. The English items constituting the questionnaire and its descriptive statistics based on the three points, i.e., disagree, no idea and agree, have been given in Appendix. (Interested readers can contact the corresponding author to obtain the Persian version if necessary.)

\subsection{Procedure}

Almost all language institutes in Mashhad were contacted in person to attract their participation in the present study. Among them the Kish, Azaran College, ILI, Safir and Jihad Deneshgahi institutes allowed the researchers to talk to their teachers offering courses at advanced levels and seek their cooperation. Having the approval of the managers, some teachers allowed the researchers themselves to attend their classes and hand out the FLIS on specified dates. Most of the teachers, however, administered the questionnaire themselves and submitted them to the researchers the 
following day. Neither the researchers nor the teachers faced any problem in the process of administering the questionnaire and collecting the data.

\subsection{Data Analysis}

The SPSS version 19.0 was employed to obtain the descriptive statistics and conduct inferential analyses. First, the reliability of the FLIS was estimated via Cronbach's Alpha. The relationships among the items comprising its items were then explored by employing Pearson correlation estimates and the differences in the responses of various groups on the FLIS and its factors were explored by subjecting them to Independent Samples T-Test. Following Khodadady $(2009,2010)$ and Khodadady and Yassami (2012) Principal Axis Factoring was employed to extract the latent variables underlying the FLIS and Kaiser criterion, i.e., eigenvalues higher than 1, was used to determine their number. Based on Khodadady and Hashemi's (2010) suggestion the unrotated factor matrix was skipped and all correlation coefficients along with their frequency and magnitudes were estimated and reported to test the following four hypotheses.

1. The 30 items comprising the foreign Language Identity Scale (FLIS) will correlate highly among themselves.

2. The factors extracted from the FLIS will correlate significantly with it and with each other.

3. The mean scores of the participants who have planned to travel abroad will be significantly higher than those who have not on the FLIS and its factors.

4. The educational level of participants will be significantly related to the FLIS and its factors

\section{Results and Discussion}

The Cronbach's Alpha obtained on the 30 -item FLIS is 0.90 , indicating that it is a highly reliable measure of identity established in English as a foreign language. This high reliability coefficient places the FLIS among other psychological measures such as the Characteristics of Effective English Language Teachers (CEELT) consisting of 47 items. When Khodadady (2010) administered it to 1469 high school students, he obtained an Alpha of 0.97. Considering the number of items on the CEELT, i.e., 47, and the gender of its participants, i.e., both male and female, a reliability coefficient of 0.90 on a female-only sample can be considered very high.

Upon establishing the FLIS as a reliable measure of identity, the Kaiser-Meyer-Olkin (KMO) measure of Sampling Adequacy was estimated to find out whether employing factor analysis to extract latent variables was appropriate. The KMO statistic obtained in this study was .94. According to Kaiser and Rice (1974), KMO statistic in the .90s is marvelous, indicating that the sample selected in the study and the factor analysis employed would probably provide the best common factors. The significant Bartlett's Test of Sphericity, i.e., $\mathrm{X}^{2}=4569.221$, $\mathrm{df}=435, \mathrm{p}<.001$, indicated that the correlation matrix was not an identity matrix.

Table 1 presents the ordered initial and extracted communalities obtained from the 30 items comprising the FLIS. As can be seen, the initial communalities (IC) range from 0.15 to 0.55 . The range is noticeably smaller than what Khodadady (2010) obtained on the CEELT, i.e., 0.33 to 0.68 , indicating that the FLIS items are more heterogeneous than the CEELT. It explains why the number of factors extracted in this study, i.e., six, was more than those underlying the 47 item CEELT, i.e., five.

Table 2 presents the frequency, percent and cumulative percent of correlation coefficients (CCs) obtained among the 30 items comprising the FLIS. As can be seen, the $435 \mathrm{CCs}$ range from -.08 to .58 (Mean $=.25, \mathrm{SD}=.13$ ). These results are in sharp contrast to the range, i.e., .12 to .69 (Mean $=.40, \mathrm{SD}=.09)$, obtained on the CEELT and thus disconfirm the first hypothesis that the 30 items comprising the foreign Language Identity Scale (FLIS) will correlate highly among themselves. They also provide further support for Khodadady's (2010) argument that the factorial validation of a given questionnaire and the number of rotated factors extracted from their items depends on their homogeneity, i.e., the more conceptually related the items, the higher the correlation coefficient obtained among its constituting items and thus the fewer the number of factors extracted (p. 56)

Table 3 presents the six rotated factors extracted via Principal Axis Factoring, Varimax with Kaiser Normalization. As can be seen, item 12, By learning English, I'm getting more interested in taking part in ceremonies like Christmas, Valentine, ... and 18, In my dreams for reaching freedom, I believe I need knowing English, do not load acceptably, i.e., 0.30 and higher, on any factor, indicating that learning English as a foreign language is not necessarily related to developing an interest in foreign ceremonies like Christmas though some students did bring them up in their class discussions and expressed their desire to decorate trees in Christmas. Neither is learning English viewed as a means of reaching freedom such as human rights though some participants did express the belief that women enjoy more human rights in English speaking countries than in Iran. Contradictions such as items 12 and 18 may emphasize the fact that some topics in conversations are brought up by female interlocutors in Iran 
for social interactions only without confirming it in writing on measures such as the FLIS.

As it can also be seen in Table 3, seven items (23\%) cross load acceptably on one other factor, showing their factorial interrelationships with each other. These results provide further support for Khodadady's (2010) observation that cross loading is a common feature in measures newly designed in social sciences. Item 28, I can have a better connection with my English language teacher providing that she/he had studied in an English speaking country, shows not only a high loading on factor one (.52), but also cross loads acceptably on factors two (0.37) and three (0.32). These factors are closely related to each other because they deal with an idealized society, communication and means, indicating that English teachers are regarded as the most accessible means through whom they can acquire the ability to communicate ideally with the members of their idealized society.

Table 4 presents the descriptive statistics of the FLIS and its underlying factors with acceptably cross loading items. As can be seen, the first factor, Idealized Society, is the most reliable factor of the FLIS, i.e., $\alpha=.90$, followed by Idealized Communication, Idealized means, and Idealized Opportunities, i.e., $\alpha=.85, .81$, and .70 , respectively. The fifth factor, Global Connection, is the least reliable $(\alpha=.38)$ because it consists of two items only. Since the last factor, Global Self-Expression, contains just one item, its Alpha could not be estimated.

Table 5 presents the correlation coefficient obtained between the FLIS and its factors as well as among the factors themselves. As can be seen, with the exception of the sixth factor, Global Self-Expression, all the remaining five factors do correlate significantly not only with the FLIS but also with each other and thus confirm the second hypothesis that most of the factors extracted from the FLIS will correlate significantly with it and with each other. However, Global Self-Expression, does not show any significant relationship with Idealized Society, Idealized Communication, Idealized Opportunities and Global Connection. It does, nonetheless, correlate significantly with the FLIS $(\mathrm{r}=.17, \mathrm{p}<.01)$ and Idealized Means $(\mathrm{r}=.10, \mathrm{p}<.05)$, explaining about three and two percents of their variances, respectively.

Table 6 presents the statistics related to planning to go abroad. As can be seen, the mean scores of those who have planned to travel abroad are higher than those who have not. The Independent Samples T-Test showed that the difference in the mean scores is significant on the FLIS $(\mathrm{t}=5.767, \mathrm{df}=468, \mathrm{p}<.0001)$ and the first four factors, i.e., Idealized Society $(\mathrm{t}=5.628, \mathrm{df}=468, \mathrm{p}<.0001)$, Idealized Communication $(\mathrm{t}=6.344, \mathrm{df}=468, \mathrm{p}<.0001)$, Idealized Means $(\mathrm{t}=5.485, \mathrm{df}=468, \mathrm{p}<.0001)$, and Idealized Opportunities $(\mathrm{t}=2.457, \mathrm{df}=468, \mathrm{p}<.01)$. These results confirm the third hypothesis that the mean scores of the participants who have planned to travel abroad will be significantly higher than those who have not on the FLIS and its factors to a large extent.

The idealized nature of the FLIS is further supported in the statistics presented in Table 7. As can be seen, the mean scores of the participants who did travel abroad is no longer higher than those who did not as was the case with those who planned to go abroad. On the contrary the mean scores of those who have not travelled abroad are slightly higher than those who have though the Independent Samples T-Test did not reveal any significant difference between the two groups. These results show that once English learners travel abroad their idealized identity undergoes significant changes.

Table 8 presents the mean scores of high schools/college and undergraduate university students on the FLIS and its six factors. As can be seen, the mean scores of the former are higher than the latter on the scale and some of its factors. The Independent Samples T-Test showed the difference in the mean scores is significant on the FLIS $(\mathrm{t}=$ $2.051, \mathrm{df}=352, \mathrm{p}<.05)$ and the first three factors, i.e., Idealized Society $(\mathrm{t}=2.166, \mathrm{df}=352, \mathrm{p}<.05)$, Idealized Communication $(\mathrm{t}=2.091, \mathrm{df}=352, \mathrm{p}<.05)$, and Idealized Means $(\mathrm{t}=1.983$, $\mathrm{df}=352, \mathrm{p}<.05)$, indicating that secondary school and college students learn English as an idealized means through which they can communicate with the members of an idealized society. These results partially confirm the fourth hypothesis that the educational level of participants will be significantly related to the FLIS and its factors.

\section{Conclusion}

Iranian learners of English learn the language for a variety of purposes most of which were collected and employed as the constituting items of the questionnaire designed and named Foreign Language Identity Scale (FLIS) in this study. Its administration to 470 female learners of English and the factorial analysis of responses showed that out of 30 items 28 load acceptably on six underlying factors, i.e., Idealized Society, Idealized Communication, Idealized Means, Idealized Opportunities, Global Connection, and Global Self-Expression.

With the exception of Global Self-Expression, five factors, i.e., Idealized Society, Idealized Communication, Idealized Means, Idealized Opportunities, and Global Connection, showed significant inter correlations with each other and thus highlighted the importance of English in creating an idealized identity through which Iranian learners may communicate with the members of an idealized society and find idealized opportunities. For example, 350 
participants (74\%) agreed with the first item, i.e., I believe in English speaking countries, there are better living conditions, which had the highest loading on Idealized Society (.63).

The idealized nature of identity established in English as a foreign language reveals itself in learners' educational level and planning to go abroad. While high school/college students' English helps them establish an Idealized Society, embark on Idealized Communication, and acquire Idealized Means, it loses such a role for undergraduate university students. Similarly, the learners who plan to travel abroad hope to achieve Idealized Communication, access Idealized Means and explore Idealized Opportunities in an Idealized Society. However, those who have already visited abroad do not reveal any idealized identity significantly different from those who have not.

It remains, however, to be investigated whether the idealized identity measured by the FLIS has the same underlying factors for male learners of English. It will also be of great educational value to find out whether the idealized identity is established at elementary and intermediate levels of foreign language learning and whether the FLIS shows any relationships with variables such as motivation, language achievement and proficiency.

\section{References}

Gumperz, J. (Ed.). (1982). Language and social identity. Cambridge: Cambridge University Press.

Hashimoto, K. (2000). Internationalisation is 'Japanisation': Japan's foreign language education and national identity. Journal of Intercultural Studies, 21(1), 39-51. http://dx.doi.org/10.1080/07256860050000786

Heller, M. (1987). The role of language in the formation of ethnic identity. In J. Phinney, \& M. Rotheram (Eds.), Children's ethnic socialization (pp. 180-200). Newbury Park, CA: Sage.

Heller, M. (1995). Language choice, social institutions, and symbolic domination. Language in Society, 24, $373-405$. http://dx.doi.org/10.1017/S0047404500018807

Heller, M. (1999). Linguistic minorities and modernity: A sociolinguistic ethnography. London: Longman.

Heller, M. (2001). Gender and public space in a bilingual school. In A. Pavlenko, A. Blackledge, I. Piller, and M. Teutsch-Dwyer (Eds.), Multilingualism, second language learning, and gender (pp. 257-283). Berlin: Mouton de Gruyter.

Kanno, Y. (2000). Bilingualism and Identity: The Stories of Japanese Returnees. International Journal of Bilingual Education and Bilingualism, 3(1), 1-18. http://dx.doi.org/10.1080/13670050008667697

Khodadady, E. (2009).The Beliefs about Language Learning Inventory: Factorial Validity, Formal Education and the Academic Achievement of Iranian Students Majoring in English. Iranian Journal of Applied Linguistics (IJAL), 12(1), 115-165

Khodadady, E. (2010). Factors Underlying Characteristics of Effective English Language Teachers: Validity and Sample Effect. Iranian Journal of Applied Linguistics (IJAL), 13(2), 47-73

Khodadady, E., \& Hashemi, M. R. (2010). Construct Validity of Beliefs about Language Learning: Componential or Factorial. Ferdowsi Review, 1(1), 3-20

Khodadady, E., \& Yassami, S. (2012). Factorial Validation of a Writing Self-Regulation Scale: With and Without Acceptably Cross Loading Items. Journal of Language Teaching and Research, 3(3), xx-xx

McKinley, J., \& Sakamoto, M. (2007). Exploring Language + Identity: Nature of Code-switching among Japanese Students. Bulletin of the Faculty of Foreign Studies, Sophia University, 42, 1-28

Menard-Warwick, J. (2005). Both a fiction and an existential fact: Theorizing identity in second language acquisition and literacy studies. Linguistics and Education, 16, 253-274. http://dx.doi.org/10.1016/j.linged.2006.02.001

Mouer, R., \& Sugimoto, Y. (1986). Images of Japanese Society: A Study in the Social Construction of Reality. London: Kegan Paul International.

Ochs, E. (1993). Constructing a social identity: A language socialization perspective. Research on Language and Social Interaction, 26, 287-306. http://dx.doi.org/10.1207/s15327973rlsi2603_3

Tajfel, H. (1981). Human groups and social categories. Cambridge: Cambridge University Press. 
Table 1. Thirty items comprising the FLIS and the Initial Communalities (IC) and extraction communalities (EC) obtained via Principal Axis Factoring

\begin{tabular}{|l|l|l|l|l|l|l|l|l|l|l|l|}
\hline Items & IC & EC & Items & IC & EC & Items & IC & EC & Items & IC & EC \\
\hline I28 & 0.55 & 0.56 & I6 & 0.43 & 0.48 & I20 & 0.36 & 0.35 & I13 & 0.25 & 0.29 \\
\hline I26 & 0.53 & 0.54 & I7 & 0.43 & 0.47 & I4 & 0.34 & 0.29 & I21 & 0.25 & 0.24 \\
\hline I2 & 0.52 & 0.59 & I14 & 0.42 & 0.47 & I30 & 0.33 & 0.36 & I12 & 0.20 & 0.18 \\
\hline I27 & 0.52 & 0.53 & I11 & 0.42 & 0.44 & I24 & 0.32 & 0.35 & I5 & 0.18 & 0.22 \\
\hline I29 & 0.50 & 0.48 & I15 & 0.42 & 0.47 & I3 & 0.30 & 0.36 & I10 & 0.15 & 0.22 \\
\hline I25 & 0.44 & 0.55 & I23 & 0.40 & 0.47 & I9 & 0.27 & 0.37 & I22 & 0.15 & 0.50 \\
\hline I1 & 0.44 & 0.45 & I17 & 0.38 & 0.41 & I16 & 0.26 & 0.23 & & & \\
\hline I8 & 0.44 & 0.46 & I19 & 0.36 & 0.46 & I1 & 0.26 & 0.26 & & & \\
\hline
\end{tabular}

Table 2. The frequency (F), percent (P) and cumulative percent (CP) of 435 correlation coefficients $(\mathrm{CC})$ obtained among the 30 items

\begin{tabular}{|l|l|l|l|l|l|l|l|l|l|l|l|}
\hline $\mathbf{C C}$ & $\mathbf{F}$ & $\mathbf{P}$ & $\mathbf{C P}$ & $\mathbf{C C}$ & $\mathbf{F}$ & $\mathbf{P}$ & $\mathbf{C P}$ & $\mathbf{C C}$ & $\mathbf{F}$ & $\mathbf{P}$ & $\mathbf{C P}$ \\
\hline .58 & 1 & .2 & .2 & .33 & 12 & 2.8 & 29.0 & .12 & 7 & 1.6 & 85.5 \\
\hline .57 & 2 & .5 & .7 & .32 & 19 & 4.4 & 33.3 & .11 & 3 & .7 & 86.2 \\
\hline .56 & 1 & .2 & .9 & .31 & 11 & 2.5 & 35.9 & .10 & 5 & 1.1 & 87.4 \\
\hline .52 & 3 & .7 & 1.6 & .30 & 18 & 4.1 & 40.0 & .09 & 7 & 1.6 & 89.0 \\
\hline .50 & 1 & .2 & 1.8 & .29 & 22 & 5.1 & 45.1 & .08 & 1 & .2 & 89.2 \\
\hline .49 & 2 & .5 & 2.3 & .28 & 13 & 3.0 & 48.0 & .07 & 4 & .9 & 90.1 \\
\hline .48 & 1 & .2 & 2.5 & .27 & $\mathbf{1 1}$ & $\mathbf{2 . 5}$ & $\mathbf{5 0 . 6}$ & .06 & 5 & 1.1 & 91.3 \\
\hline .47 & 6 & 1.4 & 3.9 & .26 & 13 & 3.0 & 53.6 & .05 & 7 & 1.6 & 92.9 \\
\hline .46 & 1 & .2 & 4.1 & .25 & 14 & 3.2 & 56.8 & .04 & 3 & .7 & 93.6 \\
\hline .45 & 3 & .7 & 4.8 & .24 & 13 & 3.0 & 59.8 & .03 & 2 & .5 & 94.0 \\
\hline .44 & 8 & 1.8 & 6.7 & .23 & 14 & 3.2 & 63.0 & .02 & 6 & 1.4 & 95.4 \\
\hline .43 & 1 & .2 & 6.9 & .22 & 6 & 1.4 & 64.4 & .01 & 3 & .7 & 96.1 \\
\hline .42 & 9 & 2.1 & 9.0 & .21 & 11 & 2.5 & 66.9 & .00 & 1 & .2 & 96.3 \\
\hline .41 & 9 & 2.1 & 11.0 & .20 & 8 & 1.8 & 68.7 & -.01 & 5 & 1.1 & 97.5 \\
\hline .40 & 6 & 1.4 & 12.4 & .19 & 14 & 3.2 & 72.0 & -.02 & 3 & .7 & 98.2 \\
\hline .39 & 7 & 1.6 & 14.0 & .18 & 13 & 3.0 & 74.9 & -.03 & 3 & .7 & 98.9 \\
\hline .38 & 7 & 1.6 & 15.6 & .17 & 8 & 1.8 & 76.8 & -.04 & 1 & .2 & 99.1 \\
\hline .37 & 11 & 2.5 & 18.2 & .16 & 7 & 1.6 & 78.4 & -.06 & 1 & .2 & 99.3 \\
\hline .36 & 11 & 2.5 & 20.7 & .15 & 15 & 3.4 & 81.8 & -.07 & 2 & .5 & 99.8 \\
\hline .35 & 9 & 2.1 & 22.8 & .14 & 6 & 1.4 & 83.2 & -.08 & 1 & .2 & 100.0 \\
\hline .34 & 15 & 3.4 & 26.2 & .13 & 3 & .7 & 83.9 & Total & $\mathbf{4 3 5}$ & 100.0 & \\
\hline
\end{tabular}


Table 3. Six factors extracted from FLIS with their ACLIs

\begin{tabular}{|c|c|c|c|c|c|c|c|c|c|c|c|c|c|}
\hline \multirow{2}{*}{ Items } & \multicolumn{6}{|c|}{ Factors } & \multirow{2}{*}{ Items } & \multicolumn{6}{|c|}{ Factors } \\
\hline & 1 & 2 & 3 & 4 & 5 & 6 & & 1 & 2 & 3 & 4 & 5 & 6 \\
\hline 1 & .46 & * & .36 & * & * & * & 16 & .35 & $*$ & $*$ & * & $*$ & $*$ \\
\hline 2 & .37 & * & .57 & * & $*$ & $*$ & 17 & .46 & $*$ & $*$ & * & $*$ & $*$ \\
\hline 3 & $*$ & $*$ & .51 & $*$ & $*$ & $*$ & 18 & $*$ & $*$ & $*$ & * & $*$ & $*$ \\
\hline 4 & .39 & $*$ & * & $*$ & $*$ & $*$ & 19 & $*$ & $*$ & * & .59 & $*$ & $*$ \\
\hline 5 & $*$ & $*$ & .44 & $*$ & $*$ & $*$ & 20 & .36 & $*$ & .31 & $*$ & $*$ & $*$ \\
\hline 6 & .63 & $*$ & $*$ & $*$ & $*$ & * & 21 & $*$ & $*$ & $*$ & .31 & $*$ & $*$ \\
\hline 7 & $*$ & * & .55 & $*$ & $*$ & * & 22 & $*$ & $*$ & $*$ & $*$ & $*$ & .70 \\
\hline 8 & .56 & $*$ & $*$ & $*$ & $*$ & * & 23 & $*$ & .58 & * & $*$ & $*$ & $*$ \\
\hline 9 & $*$ & $*$ & $*$ & $*$ & .47 & * & 24 & $*$ & .50 & $*$ & $*$ & * & $*$ \\
\hline 10 & $*$ & $*$ & $*$ & $*$ & .45 & $*$ & 25 & $*$ & .67 & $*$ & $*$ & $*$ & $*$ \\
\hline 11 & .59 & $*$ & * & $*$ & $*$ & $*$ & 26 & .48 & .46 & $*$ & $*$ & $*$ & $*$ \\
\hline 12 & $*$ & $*$ & $*$ & $*$ & $*$ & $*$ & 27 & .45 & .47 & $*$ & * & * & $*$ \\
\hline 13 & $*$ & $*$ & $*$ & .43 & $*$ & $*$ & 28 & .52 & .37 & .32 & $*$ & $*$ & $*$ \\
\hline 14 & .41 & $*$ & $*$ & .50 & $*$ & $*$ & 29 & .43 & .43 & $*$ & $*$ & $*$ & $*$ \\
\hline 15 & $*$ & $*$ & $*$ & .57 & $*$ & $*$ & 30 & $*$ & .43 & .31 & $*$ & $*$ & $*$ \\
\hline
\end{tabular}

*Loadings less than .30

Table 4. Descriptive statistics of the FLIS and its underlying factors

\begin{tabular}{|l|l|l|l|l|l|l|l|l|}
\hline No & Factors & $\begin{array}{l}\text { No of } \\
\text { items }\end{array}$ & Mean & $\begin{array}{l}\text { Std. } \\
\text { Deviation }\end{array}$ & Alpha & Eigenvalue & $\begin{array}{l}\text { \% of } \\
\text { Variance }\end{array}$ & Cumulative \% \\
\hline 1 & Idealized Society & 14 & 72.89 & 16.095 & .90 & 3.73 & 12.43 & 12.44 \\
\hline 2 & $\begin{array}{l}\text { Idealized } \\
\text { Communication }\end{array}$ & 8 & 34.70 & 11.013 & .85 & 2.64 & 8.80 & 21.23 \\
\hline 3 & Idealized Means & 8 & 36.93 & 9.525 & .81 & 2.15 & 7.17 & 28.41 \\
\hline 4 & Idealized Opportunities & 5 & 26.24 & 5.456 & .70 & 1.97 & 6.57 & 34.98 \\
\hline 5 & Global Connection & 2 & 10.61 & 2.518 & .38 & 0.83 & 2.76 & 37.73 \\
\hline 6 & Global Self-Expression & 1 & 4.72 & 2.186 & - & 0.71 & 2.36 & 40.09 \\
\hline & FLIS & 30 & 148.11 & 29.355 & 90 & - & - & - \\
\hline
\end{tabular}

Table 5. Correlations among the factors underlying the FLIS

\begin{tabular}{|c|c|c|c|c|c|c|}
\hline FLIS and its factors & Identity & $\begin{array}{l}\text { Idealized } \\
\text { Society }\end{array}$ & $\begin{array}{c}\text { Idealized } \\
\text { Communication }\end{array}$ & $\begin{array}{l}\text { Idealized } \\
\text { Means }\end{array}$ & $\begin{array}{c}\text { Idealized } \\
\text { Opportunities }\end{array}$ & $\begin{array}{c}\text { Global } \\
\text { Connection }\end{array}$ \\
\hline Idealized Society & $.95^{* *}$ & & & & & \\
\hline Idealized Communication & $.87^{* *}$ & $.85^{* *}$ & & & & \\
\hline Idealized Means & $.87 * *$ & $.84 * *$ & $.77 * *$ & & & \\
\hline Idealized Opportunities & $.74 * *$ & $.65^{* *}$ & $.54 * *$ & $.54 * *$ & & \\
\hline Global Connection & $.33 * *$ & $.25 * *$ & $.17 * *$ & $.21 * *$ & $.26 * *$ & \\
\hline Global Self-Expression & $.17 * *$ & .06 & .08 & $.10 *$ & .07 & .05 \\
\hline
\end{tabular}

$* *$ Correlation is significant at the 0.01 level (2-tailed)

* Correlation is significant at the 0.05 level (2-tailed) 
Table 6. Planning-to-travel abroad statistics on the FLIS and its six factors

\begin{tabular}{|l|c|c|c|c|c|}
\hline \multirow{2}{*}{ FLIS and its factors } & $\begin{array}{c}\text { Planning to } \\
\text { travel }\end{array}$ & $\mathbf{N}$ & Mean & Std. Deviation & Std. Error Mean \\
\hline \multirow{2}{*}{ FLIS } & Yes & 328 & 153.08 & 27.228 & 1.503 \\
\cline { 2 - 6 } & No & 142 & 136.63 & 30.932 & 2.596 \\
\hline \multirow{3}{*}{ Idealized Society } & Yes & 328 & 75.55 & 14.578 & .805 \\
\cline { 2 - 6 } & No & 142 & 66.73 & 17.726 & 1.488 \\
\hline \multirow{3}{*}{ Idealized Communication } & Yes & 328 & 36.73 & 10.371 & .573 \\
\cline { 2 - 6 } & No & 142 & 29.99 & 11.048 & .927 \\
\hline \multirow{2}{*}{ Idealized Opportunities } & Yes & 328 & 38.47 & 8.836 & .488 \\
\hline \multirow{2}{*}{ Global Connection } & No & 142 & 33.38 & 10.122 & .289 \\
\hline \multirow{2}{*}{ Global Self-Expression } & Yes & 328 & 26.65 & 5.232 & .491 \\
\cline { 2 - 6 } & No & 142 & 25.31 & 5.853 & .137 \\
\cline { 2 - 6 } & Yes & 328 & 10.73 & 2.484 & .217 \\
\hline
\end{tabular}

Table 7. Travelled-abroad statistics on the FLIS and its six factors

\begin{tabular}{|l|c|c|c|c|c|}
\hline \multirow{2}{*}{ FLIS and its factors } & $\begin{array}{c}\text { Travelled } \\
\text { abroad }\end{array}$ & $\mathbf{N}$ & Mean & Std. Deviation & Std. Error Mean \\
\hline \multirow{2}{*}{ FLIS } & No & 276 & 149.84 & 29.782 & 1.793 \\
\cline { 2 - 6 } & Yes & 193 & 145.57 & 28.683 & 2.065 \\
\hline \multirow{2}{*}{ Idealized Society } & No & 276 & 73.92 & 16.467 & .991 \\
\cline { 2 - 6 } & Yes & 193 & 71.40 & 15.513 & 1.117 \\
\hline \multirow{3}{*}{ Idealized Communication } & No & 276 & 35.39 & 10.988 & .661 \\
\cline { 2 - 6 } & Yes & 193 & 33.69 & 11.028 & .794 \\
\hline \multirow{2}{*}{ Idealized Means } & No & 276 & 37.57 & 9.566 & .576 \\
\hline \multirow{2}{*}{ Idealized Opportunities } & Yes & 193 & 35.99 & 9.427 & .679 \\
\hline \multirow{2}{*}{ Global Connection } & No & 276 & 26.53 & 5.317 & .320 \\
\hline \multirow{2}{*}{ Global Self-Expression } & Yes & 193 & 25.80 & 5.619 & .405 \\
\hline & No & 276 & 10.47 & 2.680 & .161 \\
\cline { 2 - 6 } & Yes & 193 & 10.82 & 2.265 & .163 \\
\hline
\end{tabular}


Table 8. Educational level statistics on the FLIS and its six factors

\begin{tabular}{|c|c|c|c|c|c|}
\hline FLIS and its factors & Student & $\mathbf{N}$ & Mean & Std. Deviation & Std. Error Mean \\
\hline \multirow{2}{*}{ FLIS } & Secondary/college & 90 & 153.53 & 24.821 & 2.616 \\
\hline & Undergraduate & 264 & 146.23 & 30.493 & 1.877 \\
\hline \multirow{2}{*}{ Idealized Society } & Secondary/college & 90 & 75.79 & 13.761 & 1.451 \\
\hline & Undergraduate & 264 & 71.57 & 16.630 & 1.023 \\
\hline \multirow{2}{*}{ Idealized Communication } & Secondary/college & 90 & 36.81 & 10.833 & 1.142 \\
\hline & Undergraduate & 264 & 34.05 & 10.839 & .667 \\
\hline \multirow{2}{*}{ Idealized Means } & Secondary/college & 90 & 38.62 & 8.882 & .936 \\
\hline & Undergraduate & 264 & 36.37 & 9.439 & .581 \\
\hline \multirow{2}{*}{ Idealized Opportunities } & Secondary/college & 90 & 26.91 & 4.711 & .497 \\
\hline & Undergraduate & 264 & 25.89 & 5.561 & .342 \\
\hline \multirow{2}{*}{ Global Connection } & Secondary/college & 90 & 10.80 & 2.491 & .263 \\
\hline & Undergraduate & 264 & 10.50 & 2.597 & .160 \\
\hline \multirow{2}{*}{ Global Self-Expression } & Secondary/college & 90 & 4.69 & 1.929 & .203 \\
\hline & Undergraduate & 264 & 4.83 & 2.445 & .151 \\
\hline
\end{tabular}

\section{Appendix}

The descriptive statistics of the items comprising the FLIS and the factors upon which they have the highest acceptable loading

\begin{tabular}{|c|c|c|c|c|c|c|c|c|}
\hline No & Item & 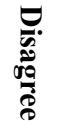 & 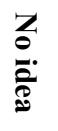 & $\frac{8}{8}$ & $\stackrel{3}{3}$ & $\tilde{\sigma}$ & 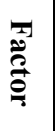 & 总 \\
\hline 1 & $\begin{array}{l}\text { Learning English is the only way through which I can be connected with my } \\
\text { favourite celebrities abroad. }\end{array}$ & 68 & 65 & 337 & 2.57 & 0.732 & 1 & 0.46 \\
\hline 2 & I can express my feelings better in English. & 134 & 84 & 252 & 2.25 & 0.872 & 3 & 0.57 \\
\hline 3 & I believe only learning English can help me in reaching my goals. & 103 & 69 & 298 & 2.41 & 0.826 & 3 & 0.51 \\
\hline 4 & $\begin{array}{l}\text { If I knew English, the natives in English speaking countries would welcome } \\
\text { me. }\end{array}$ & 34 & 48 & 388 & 2.75 & 0.576 & 1 & 0.39 \\
\hline 5 & $\begin{array}{l}\text { After learning a new topic in English, I can make mental connections with } \\
\text { the natives. }\end{array}$ & 68 & 116 & 286 & 2.46 & 0.734 & 3 & 0.44 \\
\hline 6 & I believe in English speaking countries, there are better living conditions. & 46 & 74 & 350 & 2.65 & 0.652 & 1 & 0.63 \\
\hline 7 & I believe only learning English can help me in overcoming my problems. & 153 & 114 & 203 & 2.11 & 0.865 & 3 & 0.55 \\
\hline 8 & I enjoy watching English peoples' lifestyle more than ours. & 105 & 82 & 282 & 2.39 & 0.866 & 1 & 0.56 \\
\hline 9 & I believe by learning English I can make more foreigner friends. & 41 & 88 & 341 & 2.64 & 0.637 & 5 & 0.47 \\
\hline 10 & I believe learning English is the only way for joining the world village. & 66 & 78 & 326 & 2.55 & 0.727 & 5 & 0.45 \\
\hline 11 & I believe 'women' enjoy more freedom in English speaking countries. & 61 & 67 & 342 & 2.6 & 0.708 & 1 & 0.59 \\
\hline 12 & $\begin{array}{l}\text { By learning English, I'm getting more interested in taking part in } \\
\text { ceremonies like Christmas, Valentine, ... }\end{array}$ & 129 & 99 & 241 & 2.3 & 1.657 & & \\
\hline 13 & By learning English, I'd get better job opportunities and prosper. & 53 & 54 & 363 & 2.66 & 0.672 & 4 & 0.43 \\
\hline
\end{tabular}




\begin{tabular}{|c|c|c|c|c|c|c|c|c|}
\hline 14 & By speaking English, I can meet more interesting people. & 40 & 75 & 355 & 2.67 & 0.626 & 4 & 0.5 \\
\hline 15 & $\begin{array}{l}\text { When I speak English, my family, relatives, my friends and the society } \\
\text { would look me up. }\end{array}$ & 51 & 56 & 363 & 2.66 & 0.664 & 4 & 0.57 \\
\hline 16 & $\begin{array}{l}\text { I prefer the characters in institute English books more than the ones in } \\
\text { school English books. }\end{array}$ & 37 & 60 & 373 & 2.71 & 0.602 & 1 & 0.35 \\
\hline 17 & I love the image of living in an English speaking country. & 21 & 63 & 386 & 2.78 & 0.513 & 1 & 0.46 \\
\hline 18 & In my dreams for reaching freedom, I believe I need knowing English. & 88 & 87 & 295 & 2.44 & 0.789 & & \\
\hline 19 & $\begin{array}{l}\text { Speaking English makes me have a better feeling of my personality inside } \\
\text { and outside of the class. }\end{array}$ & 46 & 69 & 355 & 2.66 & 0.65 & 4 & 0.59 \\
\hline 20 & $\begin{array}{l}\text { Knowing English is the only channel through which I can have } \\
\text { communication in the internet and thus can be heard. }\end{array}$ & 80 & 84 & 306 & 2.48 & 0.769 & 1 & 0.36 \\
\hline 21 & $\begin{array}{l}\text { Me, my family, and the people in my country, consider the person who does } \\
\text { not know a second language as illiterate. }\end{array}$ & 138 & 105 & 227 & 2.19 & 0.862 & 4 & 0.31 \\
\hline 22 & $\begin{array}{l}\text { English language is the only channel through which I can introduce our } \\
\text { culture and history to people in other countries. }\end{array}$ & 109 & 98 & 262 & 2.34 & 0.919 & 6 & 0.7 \\
\hline 23 & I prefer my marriage ceremony be held in English style. & 268 & 68 & 134 & 1.71 & 0.881 & 2 & 0.58 \\
\hline 24 & $\begin{array}{l}\text { I believe if I star teaching English to my child in his early childhood, he will } \\
\text { grow a better personality later on. }\end{array}$ & 102 & 56 & 312 & 2.45 & 0.826 & 2 & 0.5 \\
\hline 25 & $\begin{array}{l}\text { I believe that if my parents (or my spouse) spoke English, I could connect to } \\
\text { them better. }\end{array}$ & 172 & 90 & 208 & 2.08 & 0.897 & 2 & 0.67 \\
\hline 26 & English speaking celebrities are my favourites. & 120 & 83 & 267 & 2.31 & 0.853 & 1 & 0.48 \\
\hline 27 & I value those Iranian artists who can speak English too. & 119 & 95 & 256 & 2.29 & 0.845 & 2 & 0.47 \\
\hline 28 & $\begin{array}{l}\text { I can have a better connection with my English language teacher providing } \\
\text { that she/he had studied in an English speaking country. }\end{array}$ & 75 & 88 & 307 & 2.49 & 0.755 & 1 & 0.52 \\
\hline 29 & $\begin{array}{l}\text { I enjoy the products, stores, books, magazines, and the movies which carry } \\
\text { English names. }\end{array}$ & 114 & 62 & 294 & 2.38 & 0.85 & 2 & 0.43 \\
\hline 30 & $\begin{array}{l}\text { If I travel to an English speaking country, I would select an English name } \\
\text { for myself. }\end{array}$ & 323 & 56 & 90 & 1.52 & 0.909 & 2 & 0.43 \\
\hline
\end{tabular}

